\title{
The 1761 transit of Venus dispute between Audiffredi and Pingré
}

\author{
Luisa Pigatto \\ INAF - Astronomical Observatory of Padova, Vicolo dell'Osservatorio, 5, Padova, Italy \\ email: pigatto@pd.astro.it
}

\begin{abstract}
On 6 June 1761 the Dominican Giovanni Battista Audiffredi observed the transit of Venus in his little observatory at the Monastery of Santa Maria sopra Minerva in Rome. Soon after, he published an anonymous short report in Italian, and in the first months of 1762 he published a complete Latin essay about his transit observations. Late in 1762, and in 1765, the French abbé Alexandre-Gui Pingré, who had observed the transit at the Rodriguez Isle, to the south of the equator, presented to the French Royal Academy of Sciences the results of the solar parallax determination derived from comparison of observations made in different geographic places. He had excluded the Roman data because - he said - of the lack of a fundamental quantity, the longitude of the Monastery, concluding that the Roman observations were imperfect. In order to defend his scientific reputation, Audiffredi published two Latin essays concerning the solar parallax determination, the Investigatio parallaxis solaris in 1765 , and the De Solis parallaxis Commentarius in 1766.
\end{abstract}

\section{Introduction}

In the 18th century, Italy, fragmented into a number of more or less small States, didn't own a national Observatory like those of Paris (1667), Greenwich (1675), Berlin (1705), St. Petersburg (1725) and Vienna (1731), equipped with modern instruments which could co-ordinate astronomers in view of important astronomical events. In the first half of the century the only public Observatory, founded in 1712 and operative since 1726, was that of Bologna (Baiada et al. 1995).

Nonetheless, since the telescope was invented many scholars and amateurs of astronomy observed the sky with long and even better telescopes. Places of observations were rooms in private houses, monasteries, loggias in the aristocratic palaces, terraces and gardens. Though only on 23 December 1757 a papal Bull cancelled the prohibition against writings in favour of Copernicanism, the scientific climate in 18th-century Rome was very vivid, especially in the world of religious orders. The Religious devoted themselves to the study of modern science mainly to verify its principles with those of the Catholic Faith, but also often due to an authentic passion for science, in particular astronomy. For these reasons the Religious' scientific research was of very high quality. As an example, we mention the

famous Jesuit Ruggiero Boscovich who made astronomical observations from the terrace of the "Collegio Romano", the "Minimi" Fathers François Jacquier and Thomas Le Seur, who observed at the Monastery of "Trinità dei Monti". In 1739 - 1742, Jacquier and Le Seur edited the famous commentary to Newton's Principia which introduced Newtonianism to the learned society of the Roman papacy. Important astronomical events were carefully observed, and the results soon published. So it was for the transit of Mercury of 6 May 1753 and that of 7 November 1756. The phenomenon gave the astronomers the 
Table 1. Table 1. Observers, places and instruments for the 1761 transit of Venus observed in Italy $(1$ Parisian foot $=32.4833 \mathrm{~cm} ; 1$ Roman palm $=22.3322 \mathrm{~cm} ; 1$ Neapolitan palm $=26.4 \mathrm{~cm})$

\begin{tabular}{|c|c|c|}
\hline OBSERVER & PLACE & INSTRUMENTS \\
\hline Audiffredi & Rome & 9 Roman-palms Refractor \\
\hline \multirow{3}{*}{ Asclepi et al. } & Monastery of S. Maria sopra Minerva & 9 Roman-palms Divini Refractor \\
\hline & Rome & 5 Roman-palms quadrant \\
\hline & Collegio Romano & $\begin{array}{l}12 \text { Roman-palms Divini Refractor } \\
8 \text { Roman-palms Refractor }\end{array}$ \\
\hline Spagnius & & 20 Roman-palms Huygens Refractor \\
\hline Jacquier & Rome & not mentioned \\
\hline Le Seur & Monastery of S. Trinità dei Monti & \\
\hline Beccaria & Turin & 3 Parisian-feet Quadrant \\
\hline Canonica & Small tower at Beccaria's home & \\
\hline Revelli & & 40 Parisian-feet Refractor \\
\hline Poleni & Padova - his home & clouded sky \\
\hline Zanotti & Bologna & 2 1/2 Parisian-feet Quadrant \\
\hline Frisi & Public Observatory & 10 Parisian-feet Refractor \\
\hline Canterzani & & 22 Parisian-feet Refractor \\
\hline Marini & & 6 Parisian-feet Refractor \\
\hline Matteucci & & 8 Parisian-feet Refractor \\
\hline \multicolumn{3}{|r|}{ 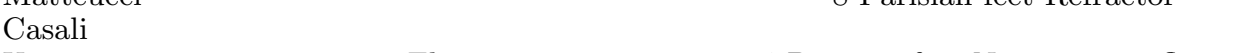 } \\
\hline Ximenes & Florence & 4 Parisian-feet Newtonian reflector \\
\hline & Specola at Collegio & \\
\hline \multirow{3}{*}{ Carcani } & S. Giovanni Evangelista & \\
\hline & Naples & 5 1/2 Neapolitan-palms Quadrant \\
\hline & Royal College & 23 1/2 Neapolitan-palms Refractor \\
\hline
\end{tabular}

opportunity to better define the elements of the planet's orbit and, at the same time, allowed them to practice for observing the very expected transit of Venus of 1761.

\subsection{The 1761 transit observed in Italy}

In western Europe, the 1761 transit of Venus should have been visible before and during the egress phase in the morning. Father Niccolò Maria Carcani of the "Scuole Pie", professor of mathematics at the Royal College of Naples, received a long letter from the famous French astronomer Joseph-Nicolas Delisle concerning the best methods to observe the transit. Following Delisle's suggestion, Carcani published the letter in the Italian journal "Novelle Letterarie" edited in Florence in order to make Delisle's advice known to Italian astronomers. Delisle suggested two different methods to observe the transit of Venus: the first method consisted of observing the differences between the transit timing of the planet's centre and that of the solar limbs seen through the horizontal and vertical wires in a quadrant. The second method consisted of observing the differences in right ascensions and declinations between the planet's centre and the solar limbs, using an equatorially mounted telescope with a good micrometer equipped with wires perpendicular and parallel to the diurnal motion of the Sun and Venus. The transit was observed, weather permitting, all around Italy, as shown in Table 1. Observations were soon published in pamphlets and in magazines (Asclepi (1761); Beccaria (1761); Poleni (1761); Zanotti (1762); Ximenes (1761); Carcani (1761)).

\section{Audiffredi's astronomical observations}

Giovanni Battista Audiffredi (1714-1794) (Fig. 1) was a Dominican who was appointed librarian in 1749 at the "Biblioteca Casanatense", the famous Library founded by the 


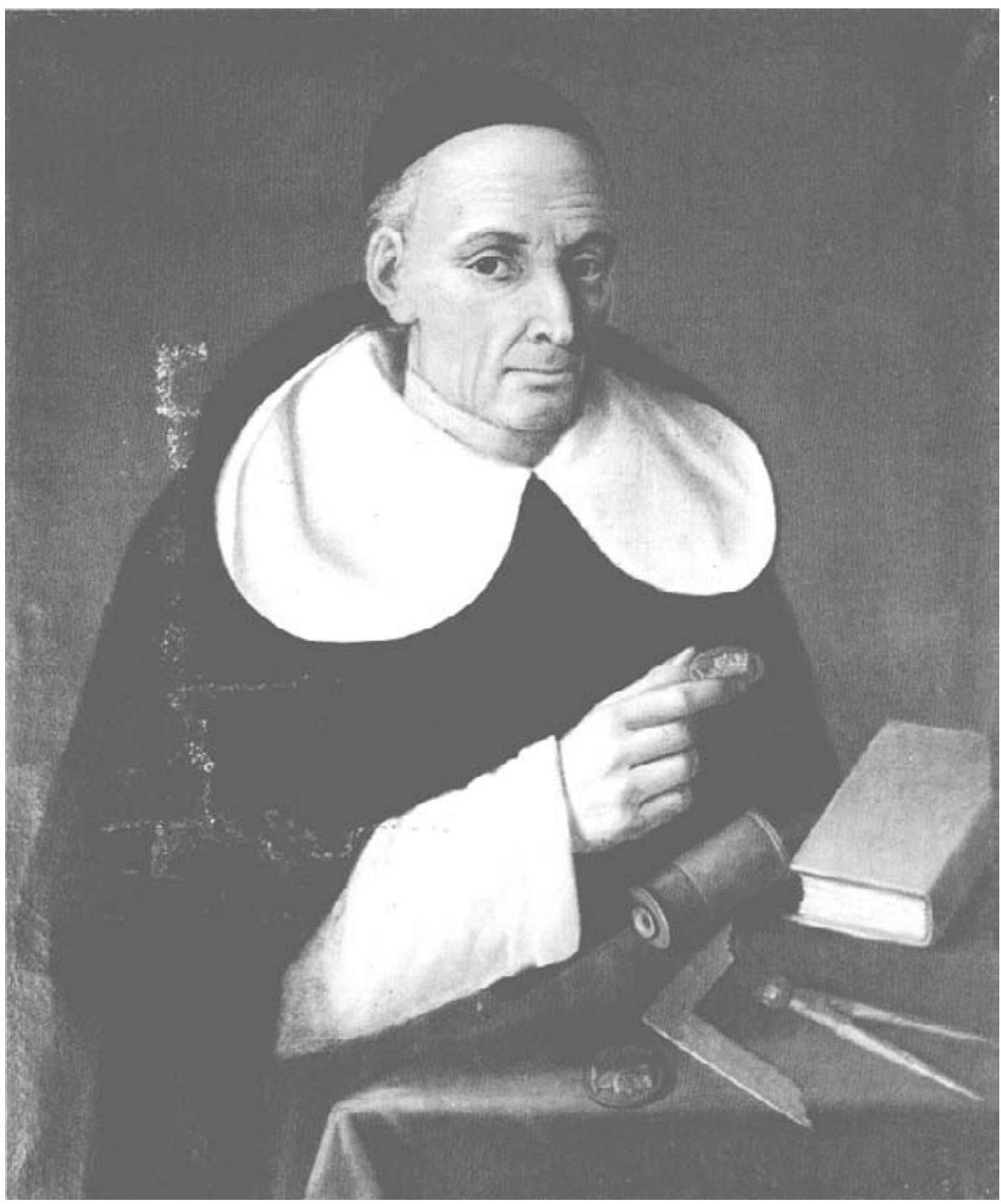

Figure 1. Oil portrait of Giovanni Battista Audiffredi.

cardinal Girolamo Casanate (1620-1700) in Rome that was inaugurated in the large complex of the Dominican Monastery of Santa Maria sopra Minerva in 1701 (Fioravanti 1994). Dominicans were known as the faithful guardians of the Catholic orthodoxy. So, it is not surprising that the Dominican Monastery was the seat of the Roman Inquisition during the 16 th and 17 th centuries. In the very same place Galileo abjured the Copernican system.

It was in the period of his new duties as Librarian that Audiffredi had a small observatory built at the top of the Monastery of Santa Maria sopra Minerva. He was very fond of astronomy since his youth, so "put astronomers' books aside", he decided he had to observe the sky directly himself (Audiffredi 1754). In 1751, as soon as he got the instruments to observe every kind of celestial phenomenon, he started to draw the meridian line with the method of the correspondent heights of the Sun, so that the line lay exactly in the meridian plane. The meridian line, engraved "over a prismatic piece 
of marble placed on a quite solid ground", fixed "with strong lime and by means of an iron web connected to the wall", was so precise that "the time didn't deviate even from a second". The gnomon was about 14 Parisian feet high; its vertex was "the centre of a hole in a brass plate about two lines thick, sized as a truncated cone" (Fioravanti 1994).

With his meridian line Audiffredi determined the Pole altitude, i.e. the latitude of his observatory $\left(41^{\circ} 54^{\prime} 33^{\prime \prime}\right)$. In the years $1751,1752,1753$ he observed eclipses of Jupiter's satellites, lunar occultation of stars, and the transit of Mercury of 6 May 1753. Comparing his results with those of Paris and Bologna observatories, he realised that some mistakes were evident in the meridian difference between Rome - St. Peter Church and Paris Observatory. From his computations he concluded that the "Minerva" Monastery was to the east of Paris Observatory by a value that couldn't be greater than $40^{\mathrm{m}} 20^{\mathrm{s}}$ (Audiffredi 1754).

\subsection{Transitus Veneris}

On 6 June 1761 Audiffredi observed the transit in his little observatory. On 13 June he published the true times of the third and fourth contacts of Venus with the solar limb in the Diario ordinario Romano; he also published a short note of his observations in an anonymous six-page booklet in Italian, and the same anonymous report appeared in the Novelle Letterarie of 1761.

Before he published his results, Audiffredi got in touch with the Religious, who had observed the phenomenon in Rome, in order to verify the reliability of his data. He contacted Jacquier and Le Seur, the Jesuit Benvento, the Fathers of the "Scuole Pie" who had observed the transit at the "Collegio Calasanzio", wrote to the Jesuit Leonardo Ximenes in Florence and to Eustachio Zanotti in Bologna. The Dominican was enthusiastic for the excellent agreement of the internal contact time recorded by him with those of the other observers, taking into account the difference of longitude. This time was one of the quantities which could be used to calculate the solar parallax.

So, in the first months of 1762 Audiffredi published a complete Latin essay, Transitus Veneris ante Solem (Fig. 2) with all his observations. As in a clear and detailed handbook, the Dominican described all the operations he had performed before, during and after the transit. The first operation was to control the delay of the pendulum clock with regard to the midday of the meridian line, in order to reduce the observations to the true time correspondent to the hour-angle of Sun and Venus. He arranged a 9-Roman-palms telescope (2 meters) with a micrometer "formed of four very thin wires crossing at 45 degrees" to observe the planet during its transit over the Sun, and a 19-Roman-palms telescope (4.24 meters), with the objective lens by the "famous Eustachio Divini", to observe the planet's egress.

He observed 33 positions of Venus over the solar disc. For each of them, he recorded the contact time of the western and eastern limb of the Sun with the vertical wire of the micrometer, the contact time of the western and eastern limb of Venus with the first oblique wire, with the vertical wire and with the second oblique wire respectively (see Fig. 3).

In order to reduce his observations, he chose the solar diameter of $31^{\prime} 37^{\prime \prime}$, made a mathematical interpolation of the planet's path, reduced the positions of Venus and Sun to the true values and determined the minimum distance from their centre by trigonometric method as shown in his drawing (Fig.4). At the end, he presented the elements of Venus's orbit he had calculated from his observations, which he communicated to his Italian colleagues, intending to calculate the Sun's parallax as soon as he could get data from other European observers. 


\section{T R A N S I T U S VENERIS ANTE SOLEM \\ O B S E R V A T I ROM E \\ Apud PP. S. Marie Super Minervamt \\ vi. JUNII MDCCLXI. \\ E X P O S I T I O \\ HISTORICO-ASTRONOMICA.

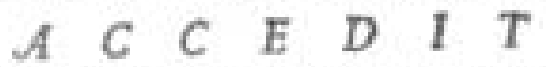 \\ DESCRIPTIOAUREI NUMMT \\ CN. DOMITII AHENOBARBI.}

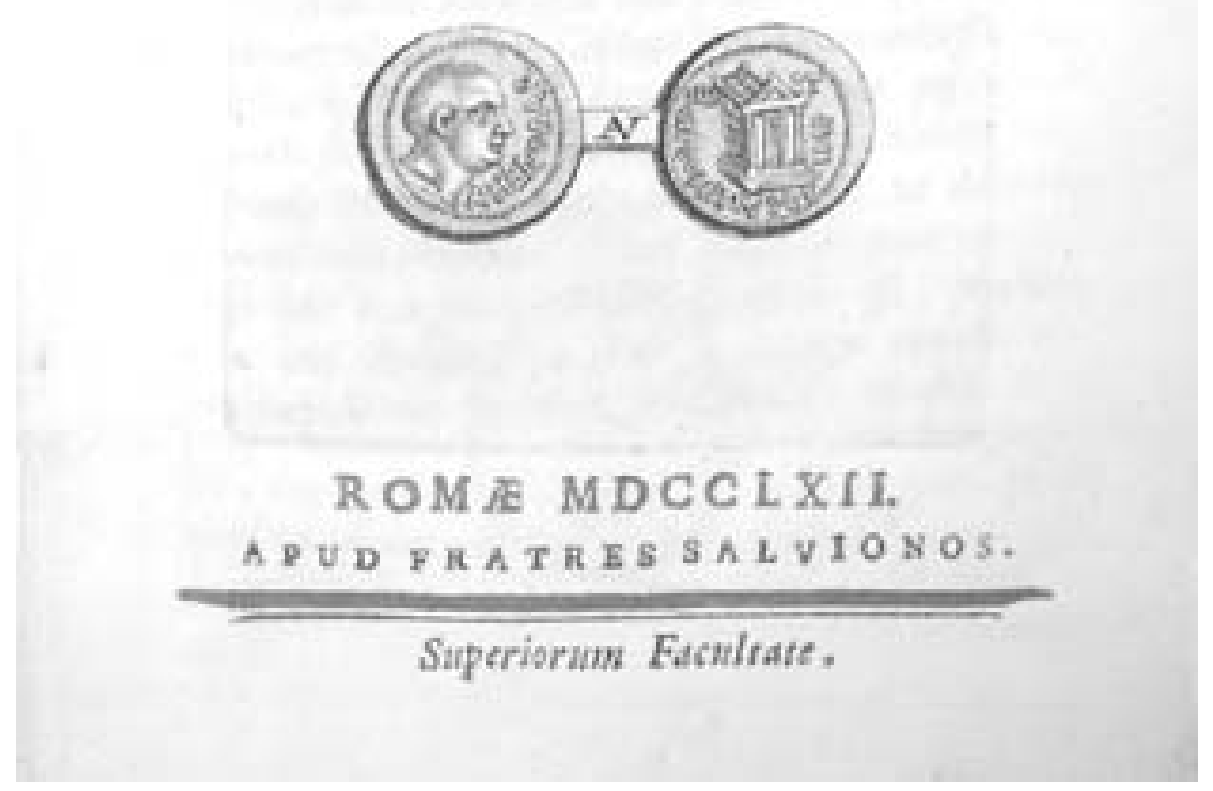

Figure 2. The frontispiece of the Venus Transit of 1762 .

\section{The affair Audiffredi - Pingré: an 'anonymous' dispute}

In late 1762, the French Abbé Alexandre-Gui Pingré (1711-1796 ) gave a detailed account of the Sun's parallax determination to the members of the French Royal

Academy. In his long memoir, he analysed the Venus transit observations that French and foreign astronomers had performed in different geographical places, and gave the 


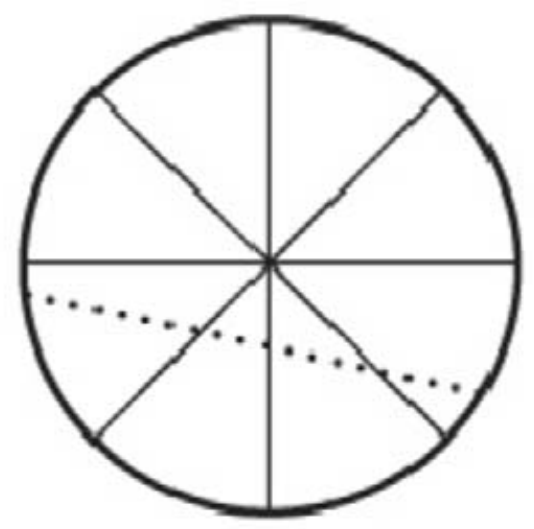

Figure 3. Scheme of the four wires micrometer. The circle represents the telescope field, dots the Venus path on it.

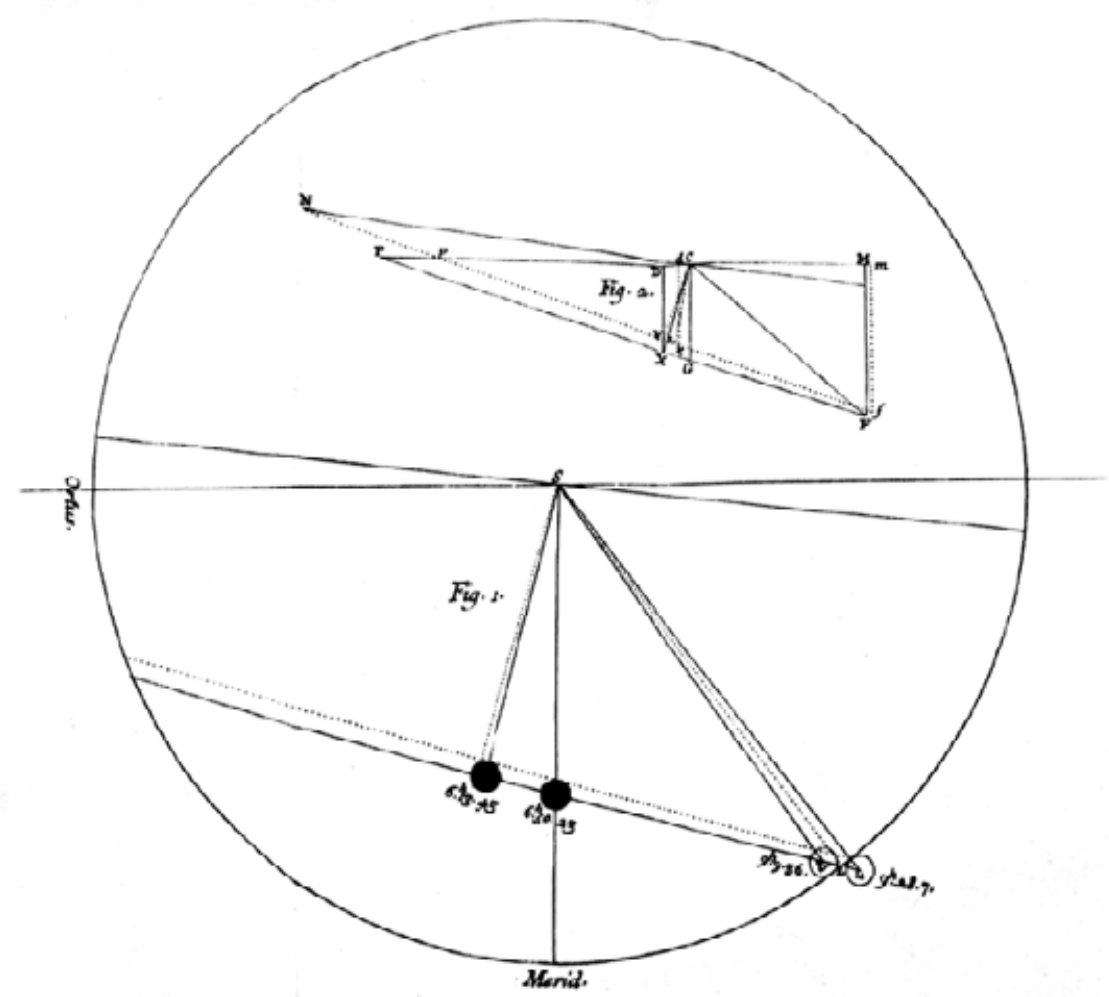

Figure 4. The drawing by Audiffredi shows the trigonometric method to determine the minimum distance between the Sun's and Venus's centres. The circle represents the solar disc.

results of his computation. For this purpose, he used three different methods: the first, by comparing the duration of the whole path of Venus over the solar disc; the second, comparing the minimum distance between the centre of Venus and Sun; the third, comparing the time of the last internal contact of Venus with the solar limb. This third method required a "very precise knowledge of the longitude of the locations where the 
end of the transit was observed", while it was sufficient to know the latitude within few minutes (Pingré 1763a).

Pingré stated that he couldn't take into account some listed observations because of the lack of the value of longitude. As far as Rome was concerned, he underlined that the Connoissance des Temps (the French ephemerides) gave the value of the St. Peter Church: "Is it there, or on the same meridian - he asked himself - that the transit of Venus was observed by an anonymous who gives the exit time at $21 \mathrm{~h} 09 \mathrm{~m} 36 \mathrm{~s}$ ? They say the place was S. Maria sopra Minerva". The abbé concluded: "In order to use the Roman observations it is necessary to know the precise difference in latitude, and especially in longitude, between the two places". This comment was not offensive at all, but it demonstrated that the only source of information was the anonymous paper Audiffredi had published in the Novelle Letterarie where the requested quantities were lacking, but where it was said: "The meridian line has been carefully examined in this same month of June during the solar eclipse, and has been found very precise" (Audiffredi 1761). It seems surprising that Pingré didn't see the following and most exhaustive work by Audiffredi, Transitus Veneris, before deriving his conclusion about the Sun's parallax. As a matter of fact, this book was published in the first months of 1762, long before Pingré could be able to come back at home from the Rodriguez Isle, where he went to observe the transit. In the very same book he should be able to find the requested value of longitude together with the name of the author, which was mentioned in the "permission to publish" at the end of the volume. Besides, not even the observations performed by Jesuits at the "Collegio Romano" were taken into account, even if the Jesuit Asclepi published them in the De Veneris per Solem Transitu (Asclepi 1761).

We assume that Audiffredi was offended by Pingré's remarks because the abbé demonstrated he had never considered, or never seen, the astronomical observations the Dominican started publishing since 1753, where it was possible to find any information concerning the small observatory at the top of the "Minerva" Monastery. So, the misunderstanding was born for many scholars' bad habit - also a habit today - not to read carefully the other authors' works or, worse, to ignore them. It was improbable that Audiffredi's book did not arrive at the prestigious Académie de France, since the Dominican, just because of his position as a "Prefect" of the most important library in Rome, certainly did take care to make new books known, in particular his books.

However, Audiffredi got a last nasty surprise when Pingré gave a second account about the Sun's parallax computation in 1765 . This paper concerned a very unpleasant dispute between James Short (1717-1768) and Pingré. As a matter of fact, the French astronomer accused his English colleague to have tried "to overthrow the building" he had started to build, giving a parallax value of 8 " 56 , well lower than the mean value of 10 " 60 calculated by Pingré himself (Pingré 1768). Short, starting from the first French memoir, wrote that Pingré seemed "to think there must be some mistake in the observation of Mr. Mason at the Cape of Good Hope, particularly with regard to the difference of longitude between Mr. Mason's observatory and Paris, because by comparing the observation of Mr. Mason at the Cape with the European observations, he finds the parallax of the Sun, from thence resulting, to be between $8^{\prime \prime}$ and $9^{\prime \prime}$, consequently differing from the determination by the observation at Rodrigues when compared with the same places" (Short 1763).

The dispute between the two astronomers was openly discussed on the pages of the two prestigious journals - the Mémoires and the Philosophical Transactions - while we can define that one with Audiffredi a hidden dispute with only one competitor. In this second memoir, Pingré mentioned, among others, the Roman observations only to demonstrate that Short's computations were wrong. In a few words, Pingré stated that the longitude determined by Mason at the Cape of Good Hope, at the time of the transit of Venus, was 
wrong, so his observations were useless. We note that European astronomers were greatly awaiting Mason's and Pingré's observations because they were the only ones made to the south of the equator, at the maximum distance in latitude with respect to the northern places, so with a maximum effect of Venus parallax.

In order to defend his own work, Pingré reviewed the observations used by Short (1764), criticising the values of longitudes the English astronomer had adopted for some places. On page 15 of his memoir the French abbé wrote: "The observation in Rome is made by an anonymous person, and it is impossible to evaluate its precision degree. On the contrary, I assume that this observation is imperfect, for the following reason: the longitude in Rome established by the author of the Memoir [Short], is the very same of St. Peter Church, but the Anonymous observed at the Monastery of Santa Maria sopra Minerva, which is $4^{\mathrm{s}} 1 / 2$ or $5^{\mathrm{s}}$ to east of St. Peter. The author makes only two comparisons with the Roman observation, and this is a very wise precaution. As a matter of fact, more comparisons could demonstrate the defect of the anonymous observation in a very clear way" (Pingré 1768). So - Pingré concluded - this observation had had to be suppressed.

This was too much for Audiffredi, even if a small footnote, added evidently at the last minute when it was impossible to change the text for printing reason, said: "In the memoir quoted in the previous footnote [Pingré, 1763a], I fixed a St. Peter longitude different from that we can find in the Connoissance des Temps, with which the Roman observation can be accepted; besides, the author became well known, the observation is no more anonymous, it is by a very intelligent astronomer, Father Audiffredi". Perhaps Pingré had seen the Investigatio parallaxis solaris Audiffredi published in 1765 to give all the details of his observations and the value he had calculated for the Sun's parallax.

We can assume that the Dominican felt highly humiliated before the members of the French Royal Academy. His revenge arrived soon after, and was much more subtle than the bibliographic ignorance and the inaccuracy of the French abbé were rough. First of all, Audiffredi wrote a letter to the perpetual secretary of the Academy, Jean-Paul Grandjean de Fouchy (1707-1788), who read it before the academicians, so "honouring him". Perhaps this was the only way to be taken into consideration by French astronomers. The correspondence between the two stimulated Audiffredi to publish, in 1766, a second Latin work about the parallax determination, De Solis parallaxi Commentarius (Fig. 5), dedicated to the same De Fouchy. In the preface of his book Audiffredi wrote that he had decided "not to be more involved in astronomers' disputes". He had got "the absolute peace of mind about the solar parallax", however maintaining his own opinion about his observations, independently from anyone who supported them.

\subsection{The Commentarius}

The Commentarius followed the same plan that the Investigatio of 1765 , as we can see comparing the titles of the four chapters. First of all Audiffredi illustrated how he was able to determine in a very precise way the 'true' difference of longitude between Rome-Minerva and Paris-Observatory, comparing astronomical observations performed by Roman and Parisian astronomers during the Sun's eclipse of 13 June 1760, the Moon's eclipse of 28 March 1755 and the transit of Mercury over the Sun of 6 May 1753 (Ch. 1); then, he re-established the difference of longitude between Paris and Stockholm starting from the difference between Rome and Stockholm (Ch. 2); he demonstrated the trigonometric method to calculate the parallax using the planet's internal contact, and how to reduce the observation to the Earth's centre (true value), given a predefined Sun's parallax (Ch. 3); finally, he determined single values of the Sun's parallax comparing the Roman observations with those of other geographic places (Ch. 4). This last chapter is divided into two sections: the first shows the calculations concerning geographical places 


\title{
FR. JOANNIS BAPTISTE AUDIFFREDII,
}

\author{
ORD. PRID. S. T. M.
}

\section{BIBLIOTHECE CASANATENSIS PREFECTI,}

\section{DE SOLIS PARALLAXI}

\section{AD V.CL.GRANDJEAN DE FOUCHY}

ACAD. SCIENT. PARIS. A SECRET.

. COMMENT'ARIUS.

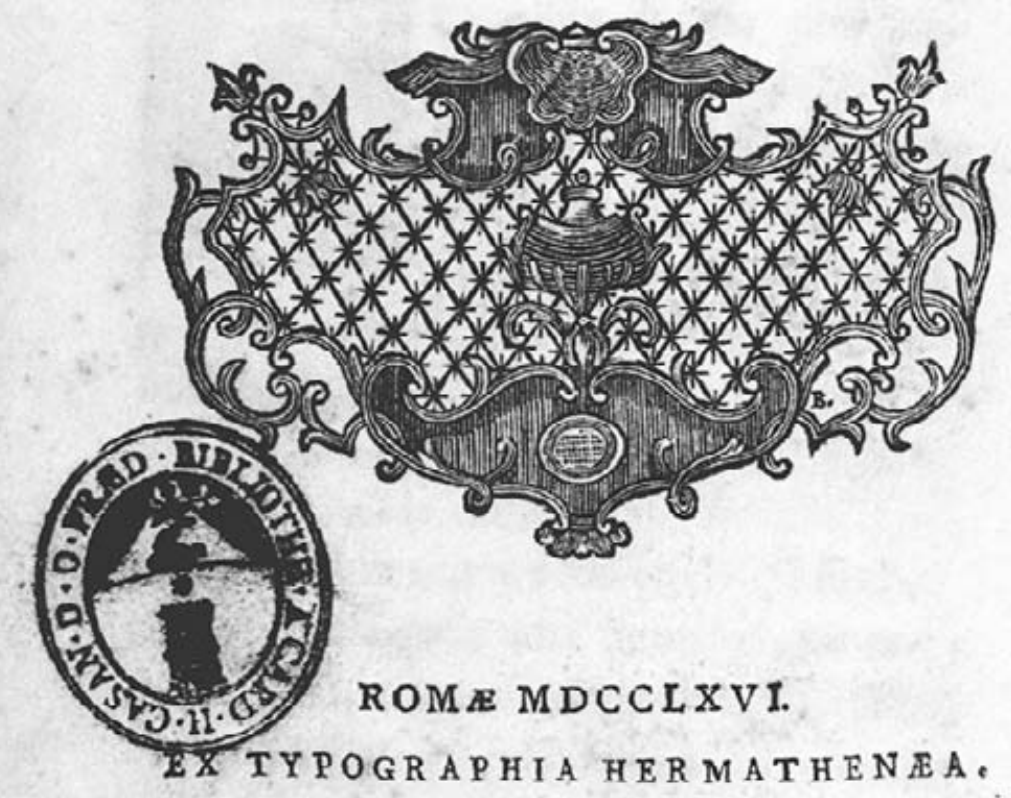

SUPERIORUM PERMISSU.

Figure 5. The frontispiece of the Commentarius of 1766 .

with well-known longitude, the second deals with the two places - the Cape of Good Hope and the Rodriguez Isle - where the English astronomer Mason and Pingré, respectively, observed the transit and at the same time determined the longitude. This chapter put an end to this peculiar dispute five years long. Audiffredi concluded that the value of the Sun's parallax derived comparing his data with Mason's at the Cape was congruent, 
Table 2. The Sun's parallax calculated by the contact method; mean value 9.'26 (Audiffredi 1766).

\begin{tabular}{|c|c|c|c|}
\hline Observation places & Time difference (calculated) & Time difference (observed) & Parallax \\
\hline Cape - Stockholm & $9^{\mathrm{m}} 56^{\mathrm{s}} .58$ & $9^{\mathrm{m}} 12^{\mathrm{s}} .00$ & $9 !^{\prime \prime} 25$ \\
\hline Cape - Greenwich & $8^{\mathrm{m}} \quad 16^{\mathrm{s}} .77$ & $7^{\mathrm{m}} 39.50$ & $9^{\prime \prime} 25$ \\
\hline Cape - Paris & $8^{\mathrm{m}} 37^{\mathrm{s}} \cdot 79$ & $7^{\mathrm{m}} 59 \mathrm{~s} .00$ & $9 .^{\prime \prime} 25$ \\
\hline Cape - Bologna & $8^{\mathrm{m}} 37^{\mathrm{s}} .79$ & $7^{\mathrm{m}} 59^{\mathrm{s}} .00$ & $9^{\prime \prime} 25$ \\
\hline Cape - Rome & $7^{\mathrm{m}} \quad 27^{\mathrm{s}} \cdot 62$ & $6^{\mathrm{m}} 54^{\mathrm{s}} 00$ & $9^{\prime \prime} 25$ \\
\hline Stockholm - Rome & $2^{\mathrm{m}} 28^{\mathrm{s}} .96$ & $2^{\mathrm{m}} 18^{\mathrm{s}} .00$ & $9 . .26$ \\
\hline Stockholm - Bologna & $2^{\mathrm{m}} 08.18$ & $1^{\mathrm{m}} 58.66$ & $9 .^{\prime \prime} 26$ \\
\hline Stockholm - Paris & $1^{\mathrm{m}} 39.81$ & $1^{\mathrm{m}} 32.50$ & $9 . .26$ \\
\hline Stockholm - Greenwich & $1^{\mathrm{m}} 18^{\mathrm{s}} .79$ & $1^{\mathrm{m}} 13.00$ & $9 !^{\prime \prime} 26$ \\
\hline Greenwich - Rome & $1^{\mathrm{m}} \quad 10^{\mathrm{s}} 17$ & $1^{\mathrm{m}} 05^{\mathrm{s}} .00$ & $9 . .26$ \\
\hline Greenwich - Bologna & $0^{\mathrm{m}} \quad 49.39$ & $0^{\mathrm{m}} \quad 45^{\mathrm{s}} \cdot 66$ & $9 .^{\prime \prime} 24$ \\
\hline Greenwich - Paris & $0^{\mathrm{m}} \quad 21^{\mathrm{s}} .02$ & $0^{\mathrm{m}} \quad 19^{\mathrm{s}} .50$ & 9.28 \\
\hline Paris - Rome & $0^{\mathrm{m}} \quad 49.15$ & $0^{\mathrm{m}} \quad 45^{\mathrm{s}} .50$ & $9 !^{\prime \prime} 26$ \\
\hline Paris - Bologna & $0^{\mathrm{m}} \quad 28^{\mathrm{s}} \cdot 37$ & $0^{\mathrm{m}} 26^{\mathrm{s}} \cdot 16$ & $9 !^{\prime \prime} 22$ \\
\hline Rome - Bologna & $0^{\mathrm{m}} \quad 20.78$ & $0^{\mathrm{m}} \quad 19.34$ & $9 . \prime 31$ \\
\hline
\end{tabular}

while the same comparison with Pingré's at the Rodriguez Isle gave a value of $11^{\prime \prime}$, very far from the truth. He demonstrated that Pingré's data gave a mistake of 5." 87 compared with Mason's, so Pingré's observations were useless. Table 2 summarises Audiffredi's 'scientific revenge'. He presented it with the following words: "To imitate in part Pingré, I submit to the reader's eyes a not inelegant table, which shows parallaxes calculated by comparison of the observations made in places with known position" (Audiffredi 1766). Obviously, the data from Rodriguez Isle are omitted.

\section{Conclusions}

In this dispute Audiffredi was the winner. He was able to demonstrate his high-level scientific preparation, his astronomical works were appreciated by the most important European astronomers, and his observations were no more criticised. May we give any extenuation to Pingré? I think so. As he told in his first memoir, Rodriguez Isle, a small volcanic isle almost desert in the Indian Ocean and French colony at that time, proved to be an uncomfortable place for the transit observation. Pingré had had to install the instruments without any technical support, the hut for the instruments was insufficient to shelter them from the wind and dust and to protect them from animals and children (Pingré 1763a). The worst came when the English invaded the isle during the Seven-years war, at the end of June, soon after the transit observation. Pingré was despairing of coming back to France and presenting in time an account of his observations to the European scientific community (Pingré 1768). For this reason he compiled a first report and tried to send a copy to London by the "same who had occupied the isle" (Pingré 1768). A very short note arrived to the French Academy and was communicated on February 1762 (Pingré 1763b). On March 1762 Pingré was in Lisbon on the way back to home, just 9 months after the Venus transit. We can assume that Pingré, for the unpleasant circumstances and the hurry to communicate his results, had made some mistakes in reducing and copying his data to send to Europe. In addition, when he arrived in Paris, it was late, thus for his calculations he took into account only the observations published in the most important European journals. 
Finally, it is notable that the scientific dispute concerned just a crucial problem of that time, i.e. the precise determination of longitude. The methods used by astronomers eclipses, occultations, lunar distances - were insufficient both for the oceanic trips and for a very precise determination of the Sun's parallax. As everybody knows, the longitude problem at sea was solved by John Harrison's timekeeper in the second half of the 18th century, after the numerous attempts of obstructionism by the Astronomer Royal Nevil Maskelyne (Howse 1997; Betts 1997).

\section{Acknowledgements}

I would like to acknowledge the Biblioteca Casanatense, Rome, for the permission to publish Audiffredi's portrait and the frontispiece of the Commentarius, the Biblioteca Universitaria of Padova for the frontispiece and table of the Transitus Veneris.

\section{References}

Asclepi, G. M. 1761 De Veneris per Solem transitu, exercitatio astronomica habita in collegio Romano Soc. Iesu a Patribus ejusdem Societatis anno 1761, Roma, typis Io. Generosi Salomoni.

Audiffredi, G.B. 1754 Phaenomena Caelestia Observata Romae, Roma, Ex Typographia Generosi Salmoni.

Audiffredi, G.B. 1761 Novelle Letterarie pubblicate in Firenze, vol. 22, col. 484-491, 500-503, $514-520$.

Audiffredi, G.B. 1762 Transitus Veneris ante Solem observati Romae Apud PP. S. Mariae super Minervam 6 Junji 1761. Expositio historico- astronomica. Accedit descriptio aurei nummi CN. Domitii Ahenobardi 1761, Roma, Ex Typographia Generosi Salmoni.

Audiffredi, G.B. 1765 Investigatio parallaxis solaris ex selectis aliquot observationibus transitus Veneris ante Solem qui accidit die 6. Junii 1761 collatis cum Romana observatione habita apud PP. S. Mariae super Minervam., Roma, ex Typographia Hermathenaea.

Audiffredi, G.B. 1766 De Solis parallaxi ad V. Cl. Grandjean de Fouchy Acad. Scient. Paris. a Secret. Commentarius, Roma, ex Typographia Hermathenaea.

Baiada, E., Bónoli, F., Braccesi, A. 1995 Museo della Specola, Bologna, University Press.

Beccaria, G.B. 1761 Novelle Letterarie pubblicate in Firenze, vol. 22, col. 471-475.

Betts, J. 1997 John Harrison, Greenwich, The National Maritime Museum.

Carcani, N.M. 1761 Novelle Letterarie pubblicate in Firenze, vol. 22, col. 696-702, 714-720.

Fioravanti, R. 1994 In Giovanni Battista Audiffredi, (ed. Angela Adriana Cavarra), Roma, 73-93.

Howse, D. 1997 Greenwich Time and Longitude, London, Philip Wilson Publishers.

Pingré, A.-G. 1763a Histoire de l'Académie Royal des Sciences, Anné 1761. Avec les Mémoires des Mathématique et de Physique, pour la même année, Paris, Mém., 413-486.

Pingré, A.-G. 1763b Histoire de l'Académie Royal des Sciences, Année 1761. Avec les Mémoires des Mathématique et de Physique, pour la même année, Paris, Mém., 87.

Pingré, A.-G. 1768 Histoire de l'Académie Royal des Sciences, Année 1761. Avec les Mémoires des Mathématique et de Physique, pour la même année, Paris, Mém., 1-34.

Poleni, G. 1761 Ad Gabrielem Manfredium ... Epistola in qua agitur de Veneris inter Solem et Tellurem transitu anno 1761, Padova.

Short, J. 1763 Phil. Trans. R. Soc., London, vol. 52, 611-628.

Short, J. 1764 Phil. Trans. R. Soc., London, vol. 53, 300-345.

Ximenes, L. 1761 Osservazione del passaggio di Venere sotto il Disco Solare accaduto la mattina del di 6 Giugno 1761, all'Osservatorio di S. Giovanni Evangelista, e ridotta al tempo del Meridiano Fiorentino, Firenze, Stamperia Imperiale.

Zanotti, E. 1762 De Veneris ac Solis congressu. Observatio habita in astronomica specula Bononiensi Die 6 Junii 1761, Bologna, typis Laelii a Vulpe. 


\section{Discussion}

Wayne Orchiston: Thank you, Luisa, for your paper. Two quick questions: firstly, does either of the telescopes that Audiffredi used still survive and, if so, are they preserved in museums?

Luisa Pigatto: No, they all disappeared. Perhaps there are some instruments in some depositories, because Audiffredi had a high position - he was a prefect of the Library. There is a museum in Rome, the "Astronomical Copernican Museum", where there is a Divini's telescope like that used by Audiffredi, but I don't know where this instrument comes from. We have to remember that in 1870 the new Italian State took over all of the buildings, instruments, libraries, and monasteries of the papal states, and then many instruments were perhaps lost.

Wayne Orchiston: My second question, which hopefully needs a shorter answer, is once Pingré became aware of the fact there wasn't a problem with the longitude of Audiffredi's observatory, did he incorporate Audiffredi's data in his final reduction to come up with the figure of 8 "' 80 for the solar parallax, or did he still not use Audiffredi's data in his final analysis?

Luisa Pigatio: Pingré didn’t take into account Audiffredi's data at all.

JESus DE AlBA: When you mentioned that a Dominican friar is involved: I remembered that the Copernicus' De revolutionibus (first edition) copy that is in Guadalajara belongs to the Dominican Monastery. It has a hand-written name, Cardinal of Capua [Nicholas Schönberg].

Luisa Pigatro: Since Dominicans compiled the index of forbidden books, the same books were in their library; it could be that a Dominican picked some books from it.

MARY BRUCK: I would like to say thank you very much for that Luisa. I didn't know about this observatory in the Church of Santa Marie sopra Minerva. And it's just fascinating because we always associate that Church with the Galileo trial, and I think most of us didn't realise that they did astronomy there. Now, I would just like to ask you a question: Were they connected with the Collegio Romano? They were the predecessors of the present Vatican, were the Jesuits. Did these Dominicans and Jesuits share their information, or did they work together in any way?

Luisa PigatTo: It doesn't seem they collaborated. For example, for this transit, Jesuits published their own observations, but they didn't mention Audiffredi's observations.

MARY BRUCK: It's strange.

Luis A PigatTo: I think that the relationship with the Jesuits was friendly, but at the same time they were in competition.

MARY BRUCK: About the meridian: you would have thought that the other place would have had their own meridian, but they didn't?

Luisa PigatTo: All the places devoted to astronomical observations had their meridian line in order to determine the true time. 
MARY BRUCK: It's just all very interesting. I would also to like to ask when did that observatory cease to exist, when did they stop doing the astronomy there? Was there any successor of Audiffredi?

Luisa PigatTo: Audiffredi's observatory at Santa Maria sopra Minerva was the Dominican's private observatory; it stopped working when Audiffredi, in his old age, stopped observing.

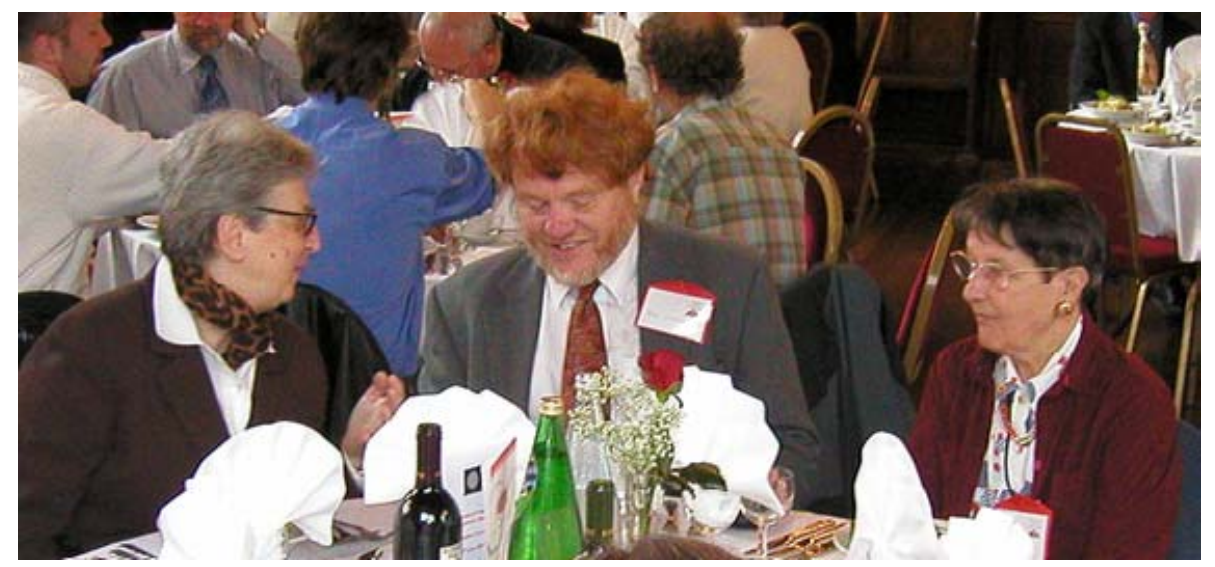

Luisa Pigatto, Jon Ponsonby and Suzanne Débarbat

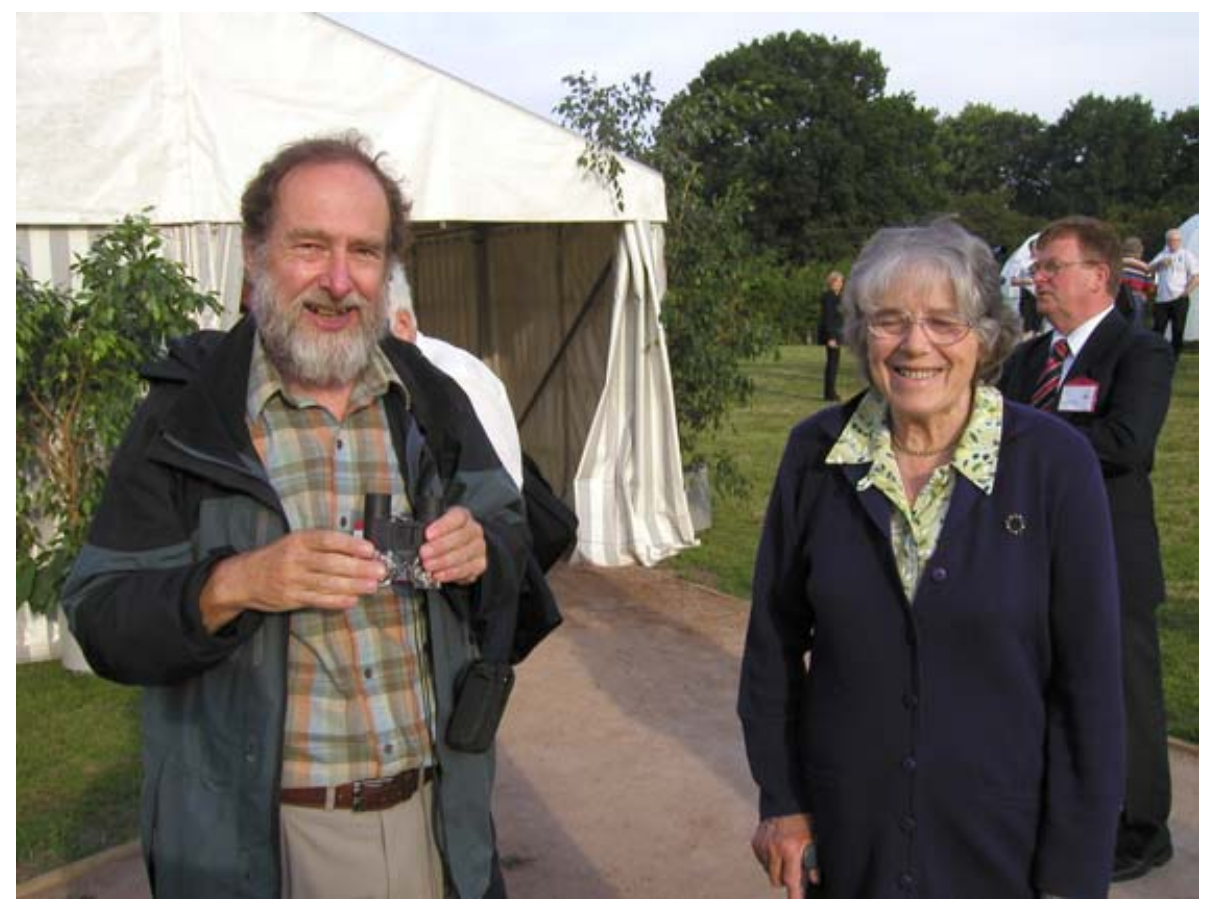

John Butler and Mary Brück 